\title{
Men's Help-Seeking and Health in Natural Disaster Contexts
}

\author{
Oscar Labra ${ }^{1}$, Gilles Tremblay ${ }^{2}$, Agustin Ependa ${ }^{1} \&$ Gabriel Gingras Lacroix ${ }^{1}$ \\ ${ }^{1}$ Department of Human and Social Developpement, University of Quebec in Abitibi-Témiscamingue, Quebec, \\ Canada \\ ${ }^{2}$ School of social Work, Laval University, Quebec, Canada \\ Correspondence: Oscar Labra, Department of Human and Social Developpement, University of Quebec in \\ Abitibi-Témiscamingue, Québec, QC., J9X 5E4, Canada. Tel: 1-819-762-0971. E-mail: Oscar.Labra@UQAT.ca
}

Received: October 7, 2017 Accepted: November 17, 2017 Online Published: November 20, 2017

doi:10.5539/gjhs.v10n1p76 URL: https://doi.org/10.5539/gjhs.v10n1p76

\begin{abstract}
Objective: The study examines masculinity practices, in both their positive and negative aspects, in terms of their influence on men's help-seeking in the context of a natural disaster, in particular the rejection of psychosocial assistance.
\end{abstract}

Methodology: Qualitative study of a small sample of voluntary participants constituted of male survivors of a major earthquake and tsunami event in 2010 in Chile.

Results: It appears that norms of hegemonic masculinity predominated in men's emotional responses to the disaster event, with both positive and negative consequences. Family relationships, mutual assistance in the community, and the passage of time emerge as the principal factors of healing for men since the catastrophe.

Discussion: An understanding of men's beliefs and attitudes is, therefore, essential to any inclusive assessment of the efficacy and quality of the various services offered to populations exposed to natural disaster events.

Keywords: men, help-seeking, health, positive masculinity practices, natural disaster

\section{Introduction}

\subsection{Introduce the Problem}

Men's health is shaped by numerous determinants, whether in the course of everyday life or following exposure to a traumatic event. According to Bizot, Viens, and Moisan (2013), such factors as the possibility of asking for help from someone close, the support of a spouse, the perception that a professional consultation is necessary, as well as the offer of health and social services, can all either motivate or dissuade men's help-seeking behaviors in such areas as mental health, paternity, economic vulnerability or violence.

The relevant literature suggests that men are likely to cumulate diverse psychological distress factors. For example, men are proportionally more likely than women to report low levels of social support (J. Roy, Tremblay, Cazale, Cloutier, \& Lebeau, 2017; Taylor, 2011) and less likely seek help from social services (Houle, Mishara, \& Chagnon, 2005; Julien, Julien, \& Lafontaine, 1998; Vogel, Heimerdinger-Edwards, Hammer, \& Hubbard, 2011), particularly within the 25-44 age group (Léveillée, 2015; Tremblay, 2005). Moreover, as has been noted in previous studies concerned with disaster contexts, the level of satisfaction relative to received help is an important factor in the presence of post-disaster psychological health problems (Danielle Maltais, Lachance, Brassard, \& Dubois, 2005). As reported by Houle et al. (2005) and Lajeunesse et al. (2013), men are less likely to talk about emotions and sources of distress, and more likely to focus on what they perceive as objective facts. Indeed, proportionally, twice as many men $(14.3 \%)$ as women $(7.6 \%)$ report having no one to confide in (Bergeron \& Cloutier, 2005). The conclusions of Nam et al. (2010), Rondeau (2004) and Tremblay, Fonséca, and Lapointe-Goupil (2004) indicate that, generally, men are less inclined than women to place trust in psychosocial services. Paralleling these findings, Antil, Bergeron and Cloutier (2005) observed that fewer men than women reported having consulted with a health or social services professional over a one year period (Antil, Bergeron, \& Cloutier, 2005). In the words of one author: "men act retroactively, post-crisis" (Dulac, 1997, p. 16; Oliffe, Ogrodniczuk, Bottorff, Johnson, \& Hoyak, 2012; P. Roy, Tremblay, \& Robertson, 2014). In addition, a number of authors (Tremblay \& Déry, 2010; Tremblay, Morin, Desbiens, \& Bouchard, 2007; Yousaf, Grunfeld, \& Hunter, 2015) have observed that men tend to perceive symptoms of distress relatively late, avoid health professionals and 
prevention measures, adopt extreme or high risk behaviors, and to delay consulting until their condition makes it unavoidable. It is therefore not surprising to find that men with more 'traditional' mindsets, make little use of external health services (Möller-Leimkühler, 2003) or other psychosocial services (Dulac, 1997; Dulac \& Groulx, 1999; Tremblay, 2005). Overall, men are hesitant to ask for help from either their social and family circles or from professional services (Tremblay et al., 2016), particularly when faced with mental and emotional difficulties (Houle et al., 2005; O’brien, Hunt, \& Hart, 2005). As the consequences of such risk behaviors for mental health are difficult to predict, health services are frequently advised to treat requests for assistance from men rapidly (B. Roy, De Koninck, Clément, \& Couto, 2012).

In terms of social roles, studies have noted that men tend to depend on their spouse for their emotional needs and to maintain social and family networks (B. Roy et al., 2012). For the vast majority of men, their spouse is the first and often the only person they turn to when experiencing personal or emotional difficulties (Tremblay et al., 2016). By extension, men living alone frequently have no one to confide in and little social support; comparatively, they are more vulnerable to isolation and distress than are women who live alone (Houle et al., 2005; Hu \& Goldman, 1990). Ai, Pappas and Simonsen (2015) for their part, note that difficult family relationships are also predictive of psychosocial difficulties in men. Employment status is an additional factor of mental health and unemployment has been linked with increased risks of psychological distress (B. Roy et al., 2012; Saint-Laurent \& Tennina, 2000), particularly in men, as demonstrated by Muller, Hicks, and Winocur (1993), who found that while employed men present higher levels of well-being than do employed women, the correspondence is diametrically inversed for the unemployed, among whom men's well-being appears to be significantly lower than women's.

Furthermore, within a social constructivist perspective, Houle, Beaulieu, Lespérance, Frasure-Smith, and Lambert (2010) and J. Roy, Tremblay, Guilmette, Bizot, and Dupéré (2014) point to a causal link between traditional modes of male socialization and diverse psychosocial difficulties in men. And although there exists a heterogeneity of masculinities, it is important to recognize that social learning among young men remains dominated, to varying degrees, by the hegemonic masculinity model as theorized by Perron (2014) and P. Roy and Tremblay (2012). Connell (1995), defines hegemonic masculinity as the prevailing configuration of practices that legitimate men's dominant position in society and justify the subordination of not only women, but also of other, marginalized modes of masculinity. As a conceptual device, the hegemonic masculinity model accounts for how and why men retain socially dominant roles, while other gender identities, identified as feminine, are marginalized. This hegemonic model of an ideal masculinity, moreover, is closely linked with social expectations of gender roles. For Segal (2007) and Nantel and Gascon (2002) the hegemonic model dictates a masculine identity of unwavering independence and invulnerability. Tension-producing and stress-inducing role conflicts emerge when rigid and restrictive gender roles, learned in the course of socialization, inhibit an individual from reaching his or her full human potential (B. Roy et al., 2012). For example, the quest for autonomy, as a fundamental vector of the traditional masculine identity, is an important factor in men's reluctance to seek help and take recourse to health and social services (Houle, Mishara, \& Chagnon, 2008; J. Roy et al., 2014); and it is worth noting that this behavior appears especially prevalent in rural contexts (Courtenay, 2011; P. Roy \& Tremblay, 2012).

As noted previously by Dulac (2001) and Perron (2014), prevailing modes of male socialization inhibit help-seeking in men, perpetuating the perception that asking for help is a sign of weakness and non-masculinity. It is important to note, however, that this model of male identity has served an important social and cultural function, which is to form individuals capable of protecting the community and to make sacrifices for the common good (Gilmore, 1990). Other authors have identified four central characteristics around which the traditional male identity is constructed: stoicism, autonomy, success and aggression (Harris, 1995; Pleck, 1981). Help-seeking requires men to reveal weaknesses and private details, while traditional male values dictate the projection of strength and privacy about one's personal life (Dulac, 2001). For Gross and McMullen (1983 as cited in Turcotte, Damant, \& Lindsay, 1995), help-seeking processes require an individual to pass through three interconnected stages, in which they must: 1) perceive that external help can curb difficulties stemming from a particular context or situation; 2) accept and confront the problematic situation, whether alone or with external assistance; and 3) adopt strategies to obtain help that addresses their specific needs. Given the findings reported in the literature, it appears that these requirements of help-seeking may present significant difficulties for many men, particularly in disaster contexts.

The foregoing review of the literature serves as a basis for the present study's objective to identify and describe the meanings that men attach to help-seeking in a natural disaster context, specifically the major earthquake and tsunami event that occurred off the coast of Chile in February 2010. The present article aims to expand on current knowledge as well as fill a gap in the literature as regards men's help-seeking in disaster contexts, particularly in relation to earthquakes and tsunami events. The present study contributes to remedy this empirical gap by 
examining the testimonies of male participants exposed to the disaster event, with a particular focus on their representations of help-seeking.

\section{Conceptual Framework}

The present study is significantly informed by both the gender role strain paradigm proposed by Pleck (1995) and the salutogenic approach of Antonovsky (1979). For Pleck (1995), men's and women's representations of gender roles are highly influenced by what they perceive as appropriate in view of social constructions of masculinity and femininity. Furthermore, Pleck (1995) describes how hegemonic masculinity determines the ways in which men are socialized from an early age and how, within this socialization framework, men's identity development strategies are constructed as a function of their relative adherence or resistance to the dominant model of masculinity (Pleck, 1995). It is through socialization that men and women integrate the norms and expectations that inform behaviors perceived as masculine or feminine. Thus, men seek strategies through which to conform to ideal models (Pleck, 1995) and those who do not achieve the predetermined standards see themselves as inferior and devalued. Through this process, men learn to restrain outward emotion and curb manifestations of vulnerability (Levant, 1996), in order to conform to an ideal type of masculinity, whose corollary is a fear and rejection of femininity (O'Neil, Good, \& Holmes, 1995). Gender roles, moreover, foster tensions when individuals internalize contradictory or inaccessible ideal-defining social norms. It appears that men who experience greater gender role conflicts are less likely to seek psychological help (Hayes \& Mahalik, 2000; O'brien et al., 2005) and that, among men who do seek help, gender role conflicts are related to various forms of psychological distress and are predictive of hostility, social discomfort, and obsessive-compulsive difficulties (Hayes \& Mahalik, 2000). In addition, gender role tensions and the conflicts they engender have significant consequences for depression in men. For example, men who conform to traditional norms and who fear being incompetent, vulnerable or "feminine" tend to deny or dissimulate symptoms of depression (Shepard, 2002), which consequently inhibits their help-seeking behaviors (Dulac, 2001).

In view of the above, it is essential to recognize that the majority of theories addressing the construction and consequences of male gender roles largely ignore their positive aspects and, by extension, fail to perceive their potential to inform preventive strategies that can counter their amply studied negative dimensions. One way of compensating for this omission is through the salutogenic approach (Antonovsky, 1979). One conceptual element of Antonovsky's approach stipulates a focus on the positive forces and elements in the environment that bolster health, as opposed to a focus on the causes of disease. Another is the "sense of coherence" or, in other words, the way in which individuals interpret the world as orderly, structured, and predictable. In Antonovsky's view, a perception of life as a coherent, meaningful whole that includes challenging situations equips individuals to deal with difficulties more successfully than does a focus on obstacles as disruptions or misfortunes.

\section{Method}

The present study seeks to examine participant testimonies in order to identify the meanings that men attach to help-seeking in a natural disaster context, specifically the major earthquake and tsunami event in Chile in 2010. The study is qualitative in design, involving a sample of 18 respondents from Chile's Maule region, where the disaster occurred, recruited using the networks sampling method (snowball sampling; see description below). The qualitative framework proved highly effective in studying the subjective aspects of help-seeking from participants' perspectives.

\subsection{Participant Recruitment and Data Collection}

The sample was constituted using a non-probabilistic method. Initially, three participants were recruited through contact with the president of the Villa Olimpica earthquake survivors association in Maule. All participants received comprehensive information detailing the goals and implications of the study, as well as information on how their anonymity would be maintained. Additional participants were recruited using the snowball method (Goodman, 1961; Handcock \& Gile, 2011), based on references from the first participants interviewed. The snowball method proved highly successful for the purposes of the study, since each of the initial respondents was able to refer another participant who met the criteria necessary for inclusion in the study. Interview locations and schedules were established in collaboration with each participant. The data collection period extended between January and March 2014.

Data collection was carried out by the lead researcher in semi-directed, face-to-face interviews, which were recorded on audio support and transcribed integrally by a research assistant who was a native speaker of Spanish. Interviews addressed diverse themes and sub-themes in order to draw a comprehensive portrait of respondents' perspectives on their life paths and the consequences of the catastrophe on various aspects of their lives 
(psychological and physical health, changes in personal, social and family life, support received, and help-seeking) Many of the questions used were originally elaborated as part of a study into the impacts of a natural disaster that affected rural Quebec in 1996 (D. Maltais, Lachance, Brassard, \& Picard, 2002). The instrument used for the purposes of the study was a Spanish translation of a French-language questionnaire developed by D. Maltais et al. (2002); a double back-translation method was employed in order to ensure instrument validity. The analysis also took into account a number of additional themes emerging from participant interviews. Respondents' sociodemographic characteristics were collected through a short questionnaire composed exclusively of closed questions. This same instrument was used to administer the Impact of Event Scale-Revised (IES-R) (Weiss, 2007), which serves to identify the presence or absence of post-traumatic stress manifestations. The IES-R is composed of 22 items assessing intrusive experiences and avoidance responses in post-traumatic situations for which respondents were asked to indicate frequency of occurrence during the preceding week.

\subsection{Data Analysis Plan}

Collected data were processed by the lead researcher using the three-step content analysis method proposed by Strauss and Corbin (1990), consisting of codification, categorization and interpretation of data. In order to identify units of meaning during the first step, successive readings of participants' testimonies were carried out so as to elaborate a codification of the body of collected data. The second step consisted in analyzing the codified data with the aim of identifying specific categories. In addition, the established codes were further linked, regrouped and classified into more comprehensive categories. Last, the codified and categorized data were interpreted in light of the research questions.

\subsection{Ethical Considerations}

The present study was conducted in full observance of participants' human rights and in compliance with the fundamental principles asserted in the second edition of the Tri-Council Policy Statement: Ethical Conduct for Research Involving Humans (Canadian Institutes of Health Research, Natural Sciences and Engineering Research Council of Canada, \& Social Sciences and Humanities Research Council of Canada, 2010). The study did not pose risks for the psychological health of the participants. Respondents' nominative data were retained on paper in a locked file cabinet accessible only to one designated member of the research team. All participants were attributed pseudonyms in order to ensure their confidentiality during data analysis and interpretation. A consent form, approved by the ethical research committee at University of Quebec in Abitibi-Témiscamingue, was presented to participants prior to each interview. All respondents participated on an entirely voluntary basis and could at any time and without consequence opt out of the study without justifying their decision.

\subsection{Characteristics of Participants}

All 18 respondents were residents of peripheral urban neighborhoods. They were aged between 21 and 79, with an average age of 57 . In terms of education levels, $(n=14)$ had completed secondary studies, while the remaining $(n=4)$ included participants with higher education and others who were illiterate. Nine of 18 respondents had a spouse and children. In terms of socio-professional groupings, two-thirds of the participants were laborers in sectors such as transport, fisheries, plumbing and security; a minority worked in education $(n=4)$, while the remainder were retirees $(n=3)$ and students $(n=2)$. Ten participants out of 18 experienced direct exposure to the earthquake, while 8 on 18 were exposed to the resulting tsunami.

\section{Results}

The results of the present study are presented below, in four sections: (1) feelings experienced by men; (2) disorganized emergency aid mobilizes men into action; (3) help-seeking as conditioned by codes of masculinity; and (4) a positive masculine practice.

\subsection{Feelings Experienced by Men}

On February 27, 2010, Chile experienced one of the most powerful natural disasters ever recorded: an earthquake of magnitude 8.8 on the moment magnitude scale, occurring off the coast, followed by a destructive tsunami. The event resulted in significant material damages, which, as participant testimonies show, occasioned a variety of emotional responses in the population of affected areas. Among the sample of 18 participants, 3 lost their homes and all their personal belongings, while 11 experienced significant damage to their homes; 4 respondents experienced only minor or no damages to their property. The 3 participants who lost everything reported acute feelings of despair in relation to their losses, especially since for all 3 the house they lost had been their childhood home, towards which they had had strong feelings of attachment. In addition, these material losses meant they had to face the burdensome administrative bureaucracy of Chile's public system, which had been unable to provide them with definitive solutions nearly four years after the disaster event. The following testimonies are particularly 
evocative:

I felt a lot of pain and distress along with my wife because we lost the house. I lived there over 50 years. It was my house my whole life. My kids grew up there! Everything was just gone in a few seconds. I've always been active in the community and I knocked on a lot of doors to get home reconstruction going: the municipality, the regional government, the national government, etc. They all told me: "we'll find a solution for you", but there wasn't any concrete answers to my requests. It's four years now that I'm living in my son-in-law's house. Imagine how I've felt these past four years, when all that I'd been used to before was my house, my things. (Gabriel)

We lost so much that I don't even know anymore! The front of the house just fell over, completely. We had to demolish everything because we couldn't live in the house anymore [...]. That's where I'd lived all my life! You can't imagine how much that meant to me, to my family. (Aurelio)

Among the 11 participants whose homes were not destroyed but sustained heavy damage, feelings appeared to differ little from the testimonies those who lost everything. The men reported feeling deep emotional pain because of their losses. One of the chagrined respondents described his experience thus:

It was a nice adobe house. It was an old style kind of house! It wasn't a big house, but it was a nice house anyways! I felt really good there. The kitchen got so damaged that finally we had to tear it down and rebuild. The bedrooms had less damage, but all that really hurts, because it's not the house I had before. It's not the same. When I think about my house - the way it was before - I feel sad, because it had strong emotional value for me. (Adolfo)

In addition to the losses and damages to homes, participants also experienced significant losses and damages to personal belongings. Lost and damaged goods mentioned by participants included television sets, refrigerators, stoves, bedroom furniture, and dishes, among others. These losses and damages emerge as factors aggravating the stress caused by the event, in particular in relation to a sense of uncertainty about the future.

The next day I realized that not only was my house damaged a lot, but everything inside was down on the ground. It really hurt to lose to lose all my things, furniture, stove, TV. It worried me a lot, to the point where I was just thinking all the time about how I was going to get by if I didn't have the financial means. I was thinking about that all the time, all the time! I felt that I wasn't doing well (Osvaldo).

In addition, as is apparent from their testimonies, participants experienced difficult family relations following the disaster, because feelings of anger and powerlessness were channeled towards the family. One respondent expressed this in the following terms:

I felt overwhelmed by the situation, disaster everywhere and no resources to recuperate what I'd lost. All that put me in a very bad mood, even towards my children and my wife. We talked a lot afterwards about how things had returned to being calm, but I just felt enraged, angry at what happened. My wife, when she felt that I was mad, she preferred to just take some distance, otherwise we would just fight. (Luis Armando)

The participant testimonies cited above are examples of the prevalence of negative emotions men experienced following the disaster event. Indeed, at the time of data collection, four years after the disaster event, such emotions as emotional pain and despair were still present. Clearly, for these men, the emotional value of the things they had lost took precedence over material value.

\subsection{Disorganized Emergency Aid Mobilizes Men into Action}

The present section will address assistance received during the crisis. According to participants, the emergency aid delivered by local and governmental bodies was haphazard and badly organized. When asked the question "Did you receive help following the earthquake or tsunami?", $77 \%$ of participants answered "yes", while $23 \%$ reported not having received any help. Those who did receive assistance reported that it came in the form of emergency aid, limited to the initial post-disaster crisis: "Here, the trucks were coming with food, clothes for the children and things like that" (Christian). Respondents also made mention of logistical difficulties in the period following the disaster as a source of anger at the inefficient distribution of aid. The following testimony is one example:

People weren't letting the aid trucks get through. Everybody was crowding around to get what they could and those who needed the most got nothing. It was badly organized. Some of the people were really nice about bringing everything, but it was all so disorganized. (Ramon)

Other respondents stated that, for example, they received food aid, but no utensils with which make proper use of it. The overall perception of the emergency aid from various levels of government was that it was badly adapted to the conditions of those affected. In the view of many participants, the inefficient coordination of services engendered tensions within the community. Furthermore, those who did not receive any aid were more critical of municipal and other authorities, feeling that they had been left to their own devices. The following testimonies provide telling 
examples:

I didn't get any kind of help, nothing at all! The social worker didn't come to our house. We didn't get any water or anything. We felt like we didn't mean anything to the authorities because they didn't they take care of us at all. (Oscar)

We felt abandoned. Instead, we got some help from people who came to give us something to eat or drink, but not the politicians and the municipal authorities. We had to organize ourselves, among neighbors, to help each other, to share food and water. (Sergio)

In answer to the question "Who helped you following the earthquake or tsunami?", participant testimonies indicate that assistance came predominantly from within the family (66\%), as well as from friends and neighbors (61\%). Only $33 \%$ of respondents received aid from their municipality, $22 \%$ from churches and $16 \%$ from the government. Overall, the testimonies indicate that assistance in the form of food, water, and shelter during the disaster came for the most part from respondents' natural support networks.

Our first response came from our neighbors! People came together so we could share what was left of the groceries and make community meals because everything was closed. There wasn't anywhere we could buy anything. The municipality and the government, they weren't ready to answer the needs of the population on February 27, and these are things I really have a hard time understanding! Chile has always been a seismic zone. We've had several major earthquakes in our recent history: in 1960 in Valdivia, and in 1985 and 1992 in this region, so it's not as if this was something new for us! (Elizeo)

I sheltered a lot of people in my yard, everyone was there! We were able to help each other, share food and water, and so forth. People were afraid to sleep at home because the tremors kept coming and coming. So it was the least I could do for them, to help each other in the neighborhood! (Rodrigo)

After the initial crisis, mutual assistance consisted in large measure of repairing and cleaning homes with the help of neighbors, friends and family. Thus the most rapid and efficient response during and following the event resulted from community generosity and self-organization: "My family came here to help me clean up, because the mud was everywhere. There was water and even sand brought in by the sea." (Sergio). Neighbors helped one another in a spirit of solidarity, protecting houses and helping to clean up. Thus, the male participants in the study not only benefitted from natural support networks, but also contributed to the support networks of others by helping in the community.

\subsection{Help-Seeking as Conditioned by Codes of Masculinity}

In terms of help sought, four years after the disaster, the great majority of respondents $(89 \%)$ reported not having had recourse to any health or social services since the event. Although they had benefitted from the type of community help described above, they appeared to have adopted an attitude of withdrawal in response to the affective impacts of their exposure to the disaster (distress, anguish, fear), focusing instead on the primary needs of their families, including reconstruction and financial needs, as well as the health of their spouses and other members of their family and social circle.

Since the earthquake, my wife hasn't been the same. She's become susceptible to all sorts of things. She's developed new illnesses. At the psychological level, she can't sleep well anymore, she's always afraid. It worries me because she's always sick with one thing or another! That's how it is today and I need to take care of her! We've been married for over 30 years already. (Luis Armando)

The majority of respondents were reticent about seeking help for the physical and psychological health complications they had developed in the four years following the disaster event, despite a deterioration in their health condition. Illnesses cited by respondents as having appeared since the disaster included: cancer, cirrhosis of the liver, fatigue, muscle and bone pain, loss of vision, and joint problems. In terms of psychological, the two principal symptoms of complications reported by participants were manifestations of depression and stress; indeed, 13 of 18 participants registered a score of 33 or higher on the IES-R scale, indicating the persistence of post-traumatic stress. Nevertheless, they appeared to perceive themselves as invulnerable and capable of withstanding any degree of suffering. As one respondent put it, when commenting on the rejection of help-seeking: "We men are tough! I'm a retired fisherman, I worked on the sea, there's a lot of suffering in that work, so I'm not afraid of tsunamis and those things." (Humberto). It is interesting to note, as well, that this stoicism was not shared by younger respondents within the sample: the two youngest participants were also the only two to have consulted with local community health services to seek help.

After the earthquake, for a few months afterwards I developed insomnia. I couldn't sleep and afterwards I wasn't 
doing well at work. My wife wanted me to go see a doctor, and that's what I did. I took pills to help with the sleeping and I think it helped a lot. (Rodrigo).

\subsection{A Positive Masculine Practice}

The following excerpts of participant testimonies illustrate how men prioritized the well-being of their families, to their own detriment. Their generosity and concern for others point to a positive masculine practice, emphasized in the following testimony:

I was concerned first and foremost with taking care of my family. My wife and my children were crying. I had to calm them as I was helping them get out of the house and get to shelter. And that's not all! My wife is sick ever since then. She was hospitalized for three months and I came close to losing her. So my first concern is to take care of her. (Rodrigo)

This positive masculine practice is also evident in the help that respondents provided to others in their community, bringing water, guarding homes from theft, and protecting those most vulnerable (the elderly, women, children and the sick). As one respondent recounted: "Once my family was safe, I ran to help our neighbors, either to get them out of their houses, help them to find water, bring food" (Adolfo), while another described how he and others "helped people who were in need, who didn't have water or blankets [...] during the night, it was cold" (Juan).

These positive masculinity practices undoubtedly helped men to get through what was an anxious experience. Respondents' answers to the question: "What helped you to get through the difficult events that followed the earthquake?" show that, rather than seek psychosocial assistance to tackle the problems that were affecting their health, men focused their attention on the needs of their family and social circle, especially during the first few months and the first year following the disaster. This was the case for 13 of 18 respondents. Once those diverse difficulties had been addressed, however, these men sought mostly to return to life as it had been before the event.

For me the priority was to take care of my family -wife and children- and the house, which was badly damaged. We couldn't think about other things. That took up a lot of my time. We had to look after a lot of things: the house, my wife was sick, work, money to fix the house! I don't have the financial resources to buy or rent another house. I earn minimum wage. (Andrés)

For $28 \%$ of respondents, what helped them to get through the difficult post-disaster period was having their family close and in good health: "Knowing that nothing happened to my family during the earthquake, that they were all alive! That was enough for me to go on" (Luis Armando). For another 22\% of participants, however, it was keeping busy at various tasks that provided a means through which to persevere.

For me the priority is always my family. After the earthquake and the tsunami, we had to start over, rebuild the house, make sure the kids had enough to eat, that we weren't missing anything. I'm the man of the house! [...] Taking of myself, I don't have time for that, even though there are moments when I'm not doing so well. (Cano)

In the absence of help-seeking, time has functioned as the main therapeutic mechanism for $67 \%$ of the sample. In the view of these men consulting with a professional is unnecessary: outside of a crippling physical affliction, time must simply be allowed to heal all wounds. The following testimonies provide insights into this attitude:

I would say that the first months after the earthquake, I didn't really have time to think of myself. We lost everything: house, furniture, everything! And my wife's health worsened after that. Luckily, we didn't lose anybody in the family. All that got to me a lot, but I was so busy taking care of my wife and making sure that the municipality was going to rebuild the house, that it's like I was just elsewhere. And I think that time has helped me to get over all that, even though I feel that today I'm not like I was before, like sometimes for example I don't even feel like getting up. I just want to sleep a lot! It's in moments like those that I tell myself: "I have to go on because I've got my old girl with me and I have to be with her". (Oscar)

I've never been a person who went to the doctor a lot and things like that. If I have a problem I can't deal with or something hurts me in there [pointing to his head], it just goes away with time and it's always been like that. Time heals everything. It's the same thing when you're heartbroken over love. Time puts things in their place, that's how it works, for me at least. (Sergio)

These testimonies demonstrate that positive masculinity practices were present during the crisis and in the post-disaster phase and, moreover, that they have continued over time. These practices play a two-sided role in the everyday experience of participants. First, they engage men's selflessness, which empowers them to contribute constructively within a situation over which they have no control. However, these positive practices also potentially lead men to ignore certain symptoms of illness in the overarching belief that time heals all, thus raising their vulnerability to both physical and psychological problems. 


\section{Discussion}

The present article describes the results of a qualitative study into men's help-seeking following a major earthquake and tsunami event in February 2010, in Chile. For men living in urban centers and coastal zones, the disaster event represented an immediate danger to their physical integrity. The event and its repercussions elicited a range of emotional responses. The testimonies of men exposed to the disaster clearly communicate despair, sadness, stress and anger. These results parallel those of other studies of men's attitudes (B. Roy et al., 2012) in identifying negative emotions that persist over time (Lazaratou et al., 2008).

The help that participants received from various levels of government following the disaster was limited to emergency aid, such as food, water, and clothing. Moreover, participant testimonies suggest that aid distribution was badly organized, thus further negatively coloring men's perceptions of external help. By contrast, they held in high regard the help they received from, as well as the help they contributed to, their natural support networks. A similar finding is reported by P. Roy and Tremblay (2012) in a study of men in rural contexts, which emphasizes the positive aspects of male solidarity in community and trade union engagement. A question that must be asked, however, is why do men place greater value on the natural support networks? Is the answer to be found in gender socialization? Men seem to identify more strongly with help they provide than with help they receive. This finding follows closely that of a study by Bizot et al. (2013), who indicate that men are troubled by stereotypes identifying them with groups in need of help, because, in their view, such identification corresponds more closely with female realities. Help-seeking requires men to reveal their weaknesses, which, for Dulac (2001), goes against perceived male values, which stipulate that men must be strong and capable of surmounting obstacles.

Generally, it appears that men are less inclined than women to speak openly of their emotions, as previously shown by Houle et al. (2005) and Lajeunesse et al. (2013) and, consequently, are less drawn towards help groups. The thought framework of many men, therefore, appears dominated by a hegemonic masculinity that inhibits help-seeking. However, as the gender role strain paradigm developed by Pleck (1995) makes clear, men's gender identity is constructed by the competing impulses either to accept or resist the hegemonic masculinity, as a result of which the gender roles men develop fall somewhere within the range of social constructions of masculinity and femininity. For O'Neil et al. (1995), moreover, socialization processes define an ideal type of masculinity and imply a rejection of femininity, which, in the view of Tremblay et al. (2016), informs a construction of the male gender that inhibits the use of psychosocial services. In addition, as shown above, the results of the present study suggest that men adopt an attitude of withdrawal in relation to help seeking and this, according to Danielle Maltais et al. (2005), may have a significant impact on the incidence of psychological health complications.

Indeed, participants reported that their health had deteriorated in the four years following the disaster event, yet the majority had not taken recourse to health services. This finding lends support to J. Roy et al. (2015) who hypothesize that men tend to have difficulties evaluating their own health needs. It appears, therefore, that the codes of hegemonic masculinity carry greater force than does the burden of suffering for men, even over long periods of time, particularly in the case mental health complications (Tremblay et al., 2016). Additionally, as stated by Zakour \& Harrell (2004), those most vulnerable to the negative impacts of disaster exposure often reside in low-income areas with little access to support services and this was the case of participants in the present study residing in peripheral urban neighborhoods.

A question arises: how do men manage to get through and develop a degree of resilience to psychological and physical health problems? The results of the present study allow us to formulate some answers. First, it appears that men develop survival strategies that allow them to forego help services without showing outward signs of fragility within their family and social circles. These strategies may be termed "help factors", of which the three predominant ones are: 1) focusing one's preoccupations on the needs of family, friends and neighbors rather than on one's own; 2) concentrating on the family as a source of motivation for perseverance; and 3) resigning oneself to the passage of time as the main source of healing.

In terms of the first factor, men adopt the role of caregiver, which provides them with a sense of self-worth. This mechanism allows them to regain a sense of purpose in the act of helping, particularly in a chaotic post-disaster context. It is worth noting, as well, that in the moments immediately following the disaster, men adopted the role of family protector; then, in the following months, when certain health problems began appearing, they confided to some extent in their spouses, but still chose not to take recourse to professional services. For the participants, the family was the second important factor: that they had not lost anyone became a source of reassurance and motivation to persevere despite hardships. Studies by Tremblay et al. (2016) and Ai, Pappas, and Simonsen (2015) similarly report that the family emerges as a central value for men in post-disaster contexts. From the point of view of Antonovsky's (1979) salutogenic approach, these two strategies may be seen as conducive to a positive 
masculine practice. The participants invested and engaged in the positive aspects of their emotions and their environment in interactions with their natural support networks, both during the immediate crisis and during the post-disaster phase.

The third "help factor" or strategy men adopted in order to avoid seeking help was to rely on the passage of time to erase or filter the traces of trauma. Although the results show that nearly all participants $(n=16)$ adhered to this view, the majority presented psychological health problems, since 13 registered scores of 33 or higher on the IES-R, signifying the presence of post-traumatic stress, and all reported physical health complications. Clearly, therefore, the notion of time as a healing agent appears to be a commonly held fallacy that, unfortunately, adds to the burden of traditional models of masculinity, further hindering men's help-seeking behaviors (Dulac, 2001; Hayes \& Mahalik, 2000; Tremblay et al., 2007).

\section{Study Limits}

The results of the present study must be interpreted with caution, since the study is retrospective in design and involved a non-representative sample of the broader population exposed to the earthquake and tsunami event of 2010, in Chile. Factors such as potential memory gaps and distortions must be taken into consideration. Moreover, certain answers may have been influenced by respondents' desire to conform to social norms or, in other words, formulated to correspond to the respondents' perception of researchers' expectations. Additionally, it is not possible to extrapolate the results to other groups exposed to other natural disasters, independent of their tangible or intangible effects. Nevertheless, the characteristics of the interviews and data analysis methods employed in the present study favor the validity of its results.

\section{Conclusion}

Men's help-seeking in a natural disaster context is characterized by an attitude of withdrawal and a hegemonic masculinity which stipulates that men must be impervious to trauma, without recourse to external help, that, in this case, they must come through one of the most powerful disasters in recorded history entirely unscathed. Nevertheless, participants manifested certain coping mechanisms conducive to positive masculinity practices, in particular men's investment in their natural support networks, which helped them to pass through the various phases of the disaster event and its aftermath. An understanding of men's beliefs and attitudes is, therefore, essential to any inclusive assessment of the efficacy and quality of services offered to populations exposed to natural disaster events.

\section{Competing Interests Statement}

The authors declare that there are no competing or potential conflicts of interest.

\section{References}

Ai, A. L., Pappas, C., \& Simonsen, E. (2015). Risk and protective factors for three major mental health problems among Latino American men nationwide. American journal of men's health, 9(1), 64-75. https://doi.org/10.1177/1557988314528533

Antil, T., Bergeron, M., \& Cloutier, R. (2005). État de santé et de bien-être des hommes québécois. In G. Tremblay, R. Cloutier, T. Antil, M.-È. Bergeron, \& R. Lapointe-Goupil (Eds.), La Santé des hommes: portrait de la situation des hommes en matière de santé au Québec. Québec: MSSS.

Antonovsky, A. (1979). Health, stress, and coping. San Francisco: Jossey Bass

Bergeron, M. E., \& Cloutier, R. (2005). Qui sont les hommes québécois et quelles sont leurs conditions de vie. In G. Tremblay, R. Cloutier, T. Antil, M. E. Bergeron, \& R. Lapointe-Goupil (Eds.), La santé des hommes au Québec (pp. 31-70). Québec: Ministère de la Santé et des Services sociaux.

Bizot, D., Viens, P., \& Moisan, F. (2013). La santé des hommes: Les connaître pour mieux intervenir. Saguenay: Université du Québec à Chicoutimi et ASSS du Saguenay-Lac-Saint-Jean.

Canadian Institutes of Health Research, Natural Sciences and Engineering Research Council of Canada, \& Social Sciences and Humanities Research Council of Canada. (2010). Tri-Council Policy Statement: Ethical Conduct for Research Involving Humans Ottawa: Public Works and Government Services Canada. Retrieved from http://www.pre.ethics.gc.ca/pdf/eng/tcps2/TCPS_2_FINAL_Web.pdf

Courtenay, W. (2011). Dying to be men: Psychosocial, environmental, and biobehavioral directions in promoting the health of men and boys. New-York: Routledge.

Dulac, G. (1997). Promotion du rôle des pères: revue de littérature et analyse d'impacts prévisibles. Montréal: Université Mc Gill, Centre d'études appliquées sur la famille. 
Dulac, G. (2001). Aider les hommes-aussi. VLB.

Dulac, G., \& Groulx, J. (1999). Intervenir auprès des clientèles masculines. Théories \& Pratiques Québécoises. Montréal: Centre d'etudes appliquées sur la famille, École de service social, Université McGill.

Gilmore, D. D. (1990). Manhood in the making: Cultural concepts of masculinity. New Haven: Yale University Press.

Goodman, L. A. (1961). Snowball sampling. The annals of mathematical statistics, 148-170. https://doi.org/10.1214/aoms/1177705148

Gross, A. E., \& McMullen, P. A. (1983). Models of help-seeking process. In B. M. DePaulo, A. Nadler, \& J. D. Fisher (Eds.), New directions in helping: Help-seeking (pp. 45-70). New York: Academic Press.

Handcock, M. S., \& Gile, K. J. (2011). Comment: On the concept of snowball sampling. Sociological Methodology, 4l(1), 367-371. https://doi.org/10.1111/j.1467-9531.2011.01243.x

Harris, I. M. (1995). Messages men hear: Constructing masculinities (Vol. 1). Bristol: Taylor \& Francis.

Hayes, J. A., \& Mahalik, J. R. (2000). Gender role conflict and psychological distress in male counseling center clients. Psychology of Men \& Masculinity, 1(2), 116-125. https://doi.org/10.1037/1524-9220.1.2.116

Houle, J., Beaulieu, M.-D., Lespérance, F., Frasure-Smith, N., \& Lambert, J. (2010). Inequities in medical follow-up for depression: a population-based study in Montreal. Psychiatric Services, 61(3), 258-263.

Houle, J., Mishara, B. L., \& Chagnon, F. (2005). Le soutien social peut-il protéger les hommes de la tentative de suicide? Santé mentale au Québec, 30(2), 61-84. https://doi.org/10.7202/012139ar

Houle, J., Mishara, B. L., \& Chagnon, F. (2008). An empirical test of a mediation model of the impact of the traditional male gender role on suicidal behavior in men. Journal of affective disorders, 107(1), 37-43. https://doi.org/10.1016/j.jad.2007.07.016

Hu, Y., \& Goldman, N. (1990). Mortality differentials by marital status: an international comparison. Demography, 27(2), 233-250. https://doi.org/10.2307/2061451

Julien, M., Julien, D., \& Lafontaine, P. (1998). Environnement de soutien. Institut de la statistique du Québec, Enquête Sociale et de Santé.

Lajeunesse, S. L., Houle, J., Rondeau, G., Bilodeau, S., Villeneuve, R., \& Camus, F. (2013). Les hommes de la région de Montréal: analyse de l'adéquation entre leurs besoins psychosociaux et les services qui leur sont offerts. Montréal: Regroupement des organismes pour hommes de l'Ile de Montréal

Lazaratou, H., Paparrigopoulos, T., Galanos, G., Psarros, C., Dikeos, D., \& Soldatos, C. (2008). The psychological impact of a catastrophic earthquake: a retrospective study 50 years after the event. The Journal of nervous and mental disease, 196(4), 340-344. https://doi.org/10.1097/NMD.0b013e31816a62c6

Levant, R. F. (1996). Toward the reconstruction of masculinity. In R. F. Levant \& P. W. S. (Eds.), A new psychology of men (pp. 229-251). New York: Basic Books.

Léveillée, S. (2015). Comprendre la détresse des hommes, mieux intervenir. Psychologie Québec, 32(5, sept. 2015), 26-28.

Maltais, D., Lachance, L., Brassard, A., \& Dubois, M. (2005). Soutien social et santé psychologique de victimes d'inondations. Sciences sociales et santé, 23(2), 5-38. https://doi.org/10.3406/sosan.2005.1648

Maltais, D., Lachance, L., Brassard, A., \& Picard, L. (2002). Difficultés et effets à long terme d'une catastrophe en milieu rural : étude combinant les approches qualitative et quantitative. Revue québécoise de psychologie, 23(3), 197-217.

Möller-Leimkühler, A. M. (2003). The gender gap in suicide and premature death or: why are men so vulnerable? European archives of psychiatry and clinical neuroscience, 253(1), 1-8. https://doi.org/10.1007/s00406-003-0397-6

Muller, J., Hicks, R., \& Winocur, S. (1993). The Effects of Employment and Unemployment on Psychological Well - Being in Australian Clerical Workers: Gender Differences. Australian Journal of Psychology, 45(2), 103-108. https://doi.org/10.1080/00049539308259126

Nam, S. K., Chu, H. J., Lee, M. K., Lee, J. H., Kim, N., \& Lee, S. M. (2010). A meta-analysis of gender differences in attitudes toward seeking professional psychological help. Journal of American College Health, 59(2), 110-116. https://doi.org/10.1080/07448481.2010.483714 
Nantel, Y., \& Gascon, É. (2002). Les difficultés masculines et l'intervention sociale: une question de lien. Intervention(116), 103-111.

O'Neil, J. M., Good, G. E., \& Holmes, S. (1995). Fifteen years of theory and research on men's gender role conflict: New paradigms for empirical research. In R. F. Levant \& W. S. Pollack (Eds.), A New Psychology of Men. (pp. 164-206). New York: Basic Books.

O'brien, R., Hunt, K., \& Hart, G. (2005). 'It's caveman stuff, but that is to a certain extent how guys still operate': men's accounts of masculinity and help seeking. Social science \& medicine, 61(3), 503-516. https://doi.org/10.1016/j.socscimed.2004.12.008

Oliffe, J. L., Ogrodniczuk, J. S., Bottorff, J. L., Johnson, J. L., \& Hoyak, K. (2012). “You feel like you can’t live anymore": Suicide from the perspectives of Canadian men who experience depression. Social science \& medicine, 74(4), 506-514. https://doi.org/10.1016/j.socscimed.2010.03.057

Perron, C. (2014). Socialisation de genre, individualité contemporaine et détresse psychologique chez l'homme. (Mémoire), Université $\mathrm{du}$ Québec à Montréal. Retrieved from http://www.archipel.uqam.ca/5919/1/M13235.pdf

Pleck, J. H. (1981). The myth of masculinity. Cambridge MIT Press.

Pleck, J. H. (1995). The gender role strain paradigm: An update. In R. F. Levant \& W. S. Pollack (Eds.), A new psychology of men (pp. 11-32). New York: Basic Books.

Rondeau, G. (2004). Les hommes: s' ouvrir à leurs réalités et répondre à leurs besoins. Rapport du Comité de travail en matière de prévention et d'aide aux hommes. Québec: ministère de la Santé et des Services sociaux.

Roy, B., De Koninck, M., Clément, M., \& Couto, É. (2012). Inégalités de santé et parcours de vie: réflexions sur quelques déterminants sociaux de l'expérience d'hommes considérés comme vulnérables. Service social, 58(1), 32-54. https://doi.org/10.7202/1010438ar

Roy, J., Cazale, L., Tremblay, G., Cloutier, R., Lebeau, A., Paré, L., . . Guilmette, D. (2015). Un portrait social et de la santé des hommes au Québec : des défis pour l'intervention. Québec: Masculinités et Société.

Roy, J., Tremblay, G., Cazale, L., Cloutier, R., \& Lebeau, A. (2017). Les hommes au Québec - Un portrait social et de santé. Québec: PUL.

Roy, J., Tremblay, G., Guilmette, D., Bizot, D., \& Dupéré, S. (2014). Perceptions des hommes québécois de leurs besoins psychosociaux et de santé ainsi que leur rapport aux services - Méta-synthèse. Québec: Masculinités et Société.

Roy, P., \& Tremblay, G. (2012). Comprendre les masculinités rurales: un portrait basé sur la santé psychologique. Service social, 58(1), 68-84.

Roy, P., Tremblay, G., \& Robertson, S. (2014). Help - seeking among Male Farmers: Connecting Masculinities and Mental Health. Sociologia Ruralis, 54(4), 460-476. https://doi.org/10.1111/soru.12045

Saint-Laurent, D., \& Tennina, S. (2000). Résultats de l'enquête portant sur les personnes décédées par suicide au Québec entre le ler septembre et le 31 décembre 1996. Québec: Ministère de la santé et des services sociaux.

Shepard, A. (2002). Marlowe's Soldiers: Rhetorics of Masculinity in the Age of the Armada. Aldershot: Ashgate.

Strauss, A., \& Corbin, J. (1990). Basics of qualitative research: Grounded theory procedures and techniques (1st ed.). Newbury Park, CA: Sage Publications.

Taylor, S. E. (2011). Social support: A review. In H. S. Friedman (Ed.), The Oxford handbook of health psychology (pp. 192-217). Oxford: Oxford University Press.

Tremblay, G. (2005). La santé des hommes au Québec: Sainte-Foy: Publications du Québec.

Tremblay, G., \& Déry, F. (2010). La santé des hommes au Québec. In J.-M. Deslauriers, G. Tremblay, S. Genest-Dufault, D. Blanchette, \& J.-Y. Desgagnés (Eds.), Regards sur les hommes et les masculinités: comprendre et intervenir. Québec: Presses de l'Université Laval.

Tremblay, G., Fonséca, F., \& Lapointe-Goupil, R. (2004). Portrait des besoins des hommes québécois en matière de santé et de services sociaux. Sainte-Foy, Québec: CRI-VIFF.

Tremblay, G., Morin, M.-A., Desbiens, V., \& Bouchard, P. (2007). Conflits de rôle de genre et dépression chez les homes. CRI-VIFF Québec.

Tremblay, G., Roy, J., Guilmette, D., Sirois-Marcil, J., Beaudet, L., Bizot, D., \& Dupéré, S. (2016). Perceptions 
des hommes québécois de leurs besoins psychosociaux et de santé ainsi que leur rapport aux services. Rapport final. Québec Masculinités et Société.

Turcotte, D., Damant, D., \& Lindsay, J. (1995). Pour une compréhension de la démarche de recherche d'aide des conjoints violents. Service social, 44(2), 91-110. https://doi.org/10.7202/706694ar

Vogel, D. L., Heimerdinger-Edwards, S. R., Hammer, J. H., \& Hubbard, A. (2011). "Boys don't cry": Examination of the links between endorsement of masculine norms, self-stigma, and help-seeking attitudes for men from diverse backgrounds. Journal of Counseling Psychology, 58(3), 368-382. https://doi.org/10.1037/a0023688

Weiss, D. S. (2007). The impact of event scale: revised. In J. P. Wilson \& C. So-Kum Tang (Eds.), Cross-cultural assessment of psychological trauma and PTSD (pp. 219-238): Springer.

Yousaf, O., Grunfeld, E. A., \& Hunter, M. S. (2015). A systematic review of the factors associated with delays in medical and psychological help-seeking among men. Health psychology review, 9(2), 264-276. https://doi.org/10.1080/17437199.2013.840954

Zakour, M. J., \& Harrell, E. B. (2004). Access to disaster services: Social work interventions for vulnerable populations. Journal of Social Service Research, 30(2), 27-54. https://doi.org/10.1300/J079v30n02_03

\section{Copyrights}

Copyright for this article is retained by the author(s), with first publication rights granted to the journal.

This is an open-access article distributed under the terms and conditions of the Creative Commons Attribution license (http://creativecommons.org/licenses/by/4.0/). 